\title{
PSYCHOMETRIC PROPERTIES OF THE QUALITY OF LIFE QUESTIONNAIRE - CERVICAL CANCER 24 (QLQ CX 24) TRANSLATION TO SERBIAN
}

Radica Zivkovic Zaric ${ }^{1}$, Marija Zivkovic Radojevic ${ }^{2}$, Katarina Krasic ${ }^{2}$, Jasmina Milovanovic ${ }^{1}$, Slobodan Jankovic ${ }^{1,2}$ ${ }^{1}$ Faculty of Medical Sciences, University of Kragujevac, Serbia, Department of Pharmacology and toxicology ${ }^{2}$ Clinical Center Kragujevac, Serbia

\section{PSIHOMETRIJSKE KARAKTERISTIKE UPITNIKA O KVALITETU ŽIVOTA - KARCINOM CERVIIKSA 24 (QLQ CX 24) PREVEIDENOG NA SRPSIKI \\ Radica Živkovic Zarićl ${ }^{1}$, Marija Živkovic Radojevićn ${ }^{2}$, Katarina Krasić ${ }^{2}$, Jasmina Milovanovićl , Slobodan Jankovićl, \\ ${ }^{1}$ Fakultet Medicinskih Nauka, Univerzitet u Kragujevcu, Srbija, Katedra za Farmakologiju i toksikologiju ${ }^{2}$ Klinički Centar Kragujevac, Srbija}

\begin{abstract}
Introduction: Cancer of the cervix has a progressive character and is one of the most significant public health problems in many countries. Our research aimed to translate EORTC QLQ CX 24 (European Organization for Research and Treatment of Cancer; Quality of life questionnaire-cervical cancer 24) from English to Serbian, to create essential cultural adaptations and to analyze psychometric properties of the translation in a model of female inpatients with cancer of the cervix. Method: The QLQCX 24 was translated and adapted according to internationally established guidelines, and then tested on a sample of 100 Serbian females with cancer of the cervix. The testing was repeated three times on the same patients. We calculated the internal consistency (Cronbach's alpha), criterion validity, convergent validity, and discriminative validity of the QLQCX24. We used factor analysis to discover the original construct. Results: The Serbian translation of QLQ CX 24 showed good internal consistency, showed satisfactory reliability, and temporal stability. In the first, when was rated by the investigators Cronbach's alpha was 0.607, and one month later when the questionnaire also was rated by investigators Cronbach's alpha was 0.696. When the scale was rated by females themselves Cronbach's alpha was 0.802. Divergent as well as convergent validity tests had good results. The factorial analysis exposed six domains. Conclusion: The Serbian translation of $Q L Q C X 24$ is a trustworthy and appropriate specific instrument for measuring the quality of life in females with cervical cancer.
\end{abstract}

Keywords: quality of life, questionnaire, cervical cancer, validation, females

\section{SAŽETAK}

Uvod/Cilj: Karcinom cerviksa ima progresivni karakter i jedan je od najznačajnijih zdravstvenih problema u mnogim zemljama. Cilj našeg istraživanja jeste prevod EORTC QLQ CX24 (European Organization for Research and Treatment of Cancer; Quality of life questionnaire-cervical cancer 24) sa Engleskog na Srpski jezik, kreiranje osnovnih kulturoloških adaptacija $i$ psihometrijska analiza prevoda na uzorku žena obolelih od carcinoma cerviksa. Metod: QLQ-CX24 je preveden i adaptiran prema utvrđenim vodičima $i$ onda testiran na uzorku od 100 pacijentkinja. Testiranje je ponovljeno tri puta na istim pacijentkinjama. Izračunali smo unutrašnju konzistenciju (Cronbahova alfa), validnost kriterijuma, konvergentnu validnost $i$ divergentnu validnostza QLQ CX24. Takodje, mi smo koristili i faktorsku analizu. Rezultati: Srpski prevod QLQ CX24 pokazao je dobru unutrašnju konzistenciju, zadovoljavajuću pouzdanost $i$ temporalnu stabilnost. Prvo je upitnik popunjen od strane ispitivača $i$ Cronbahova alfaiznosila je 0.607, a jedan mesec kasnije iznosila je 0.696. Kada su skalu popunjavale same pacijentkinje Cronbahova alfa iznosila je 0.802. Diveregentna i konvergentna validnost pokazale su dobre rezultate. Faktorska analiza uočilaje šest domena. Zaključak: Srpski prevod QLQ CX24 je pouzdan $i$ odgovarajući specifični instrument za merenje kvaliteta života kod pacijentkinja sa karcinomom cerviksa.

Ključne reči: kvalitet života, upitnik, karcinom cerviksa, validacija, žene

\section{ABBREVIATIONS}

QOL-quality of life

FSFI-Female Sexual Function Index

UDI-6-Urogenital Distress Inventory short form

ICIQ-FLUTS SF-International Consultation on Incontinence Questionnaire short form/female lower urinary tract symptoms
EORTC QLQ-CX24-European Organization for Research and Treatment of Cancer; Quality of life questionnairecervical cancer 24

EORTC QLQ-C30-European Organization for Research and Treatment of Cancer; Quality of life questionnairecancer 30

ERQ-Emotional Regulation Questionnaire 


\section{INTRODUCTION}

Cancer of the cervix has a progressive character and is one of the most significant public health problems in many countries (1). According to some studies, cervical cancer is the fourth commonest cancer in women with about 500,000 cases diagnosed with cervical cancer and about 270,000 women who die from this disease every year all over the world (1-3). Although the disease is now diagnosed more readily and the management of cervical cancer is advancing, both the disease itself and the treatment modalities carry significant morbidity with a negative impact on the quality of life (QOL) $(1,4)$. Surgery can produce certain functional disorders, radiotherapy may cause injury of vaginal mucosa and chemotherapy may have a variety of undesirable effects, like diarrhea, constipation, nausea, changes in weight, and hormonal imbalance (1).

Quality of life is an important health outcome of any disease beyond traditional ones, like morbidity and mortality. Measuring QOL is also helpful for the identification of patients' problems and making the most appropriate treatment plan for individual patients (1).Numerous prognostic factors for QOL in females with cervical cancer have been studied and published in the literature. As an example, some studies found that spiritual well-being, maladaptive coping, and reproductive concerns were separately affecting QOL, other studies imply that family, social, and intimate relationship played a vital role on perception of QOL. There is also stress that this disease causes to the relationship. In the study Khalil et al., $39 \%$ of females who were married when diagnosed got separated afterwards. Seventy two percent of them attributed their divorce to the cervical cancer (4).

Several questionnaires like Female Sexual Function Index (FSFI), Vaginal Health Index, Urogenital Distress Inventory short form (UDI-6), International Consultation on Incontinence Questionnaire short form/female lower urinary tract symptoms (ICIQ-FLUTS SF) were developed to evaluate problems with the functioning of the female genitourinary system (5). The most frequently used questionnaire for measuring QLQ in females with cervical cancer is EORTC QLQ CX 24 (European Organization for Research and Treatment of Cancer; Quality of life questionnaire-cervical cancer 24) $(6,7)$. EORTC QLQ CX 24 is a scale developed specifically to deal with the quality of life amongst patients with cervical cancer, planned to be used as an attachment to the EORTC QLQ-C30 (European Organization for Research and Treatment of Cancer; Quality of life questionnaire- cancer 30) (8, 9). This scale contains 24 questions for measuring different aspects of quality of life that had been found significant by a team of professionals in females with cervical cancer. The items of the questionnaire are grouped into three groups (Symptom Experience, Body Image, Sexual /Vaginal Functioning), also with 5 single-items: sexual worry, sexual activity, and sexual enjoyment, lymphedema, peripheral neuropathy, menopausal symptoms. The quality of life of the females is inversely proportional to the marked right answer. The QLQ CX 24 usually appears to be appropriate for everyday use in clinical practice, but it was not translated and adapted to Serbian language and cultural surroundings until now.

Our research aimed to translate EORTC QLQ CX 24 from English to Serbian, to create essential cultural adaptations, and to analyze psychometric properties of the translation in a model of female inpatients with cancer of the cervix.

\section{METHODS}

All females gave written informed consent before the investigation began. The study was permitted by the Ethics Committee of Clinical Center Kragujevac, Serbia (No. 01/18-5291), and conducted according to principles laid down in the Declaration of Helsinki about experimentations on human subjects. We got permission for translation and cultural adaptation from the EORTC Study group on Quality of life for QLQ CX 24 and from author Bojana Dinic for Emotional Regulation Questionnaire (ERQ).

\section{Patients}

Final Serbian adaptation of the QLQ CX 24 was tested for reliability on female inpatients who were hospitalized for brachytherapy at the Oncology Clinic of Clinical Center Kragujevac, Serbia. The study was performed from September 2018 to October 2019. The patients fulfilling the inclusion criteria were those with cancer of the cervix, hospitalized, and educated. The exclusion criteria were: lactation, pregnancy, mood disorders, cognitive impairment (previously confirmed in a patient's medical documentation), mental retardation, and incomplete patient's files. The participation of the patients was successive nature, i.e. all patients who were at the Oncology Clinic on the day of study (and fulfilled inclusion and exclusion criteria) were offered the questionnaire. During the initial meet, the questionnaires were completed in two ways: at first, by the researcher who were questioning the patients, and second, by the females themselves one week later, at their homes. The females again finished the questionnaires by the researcher one month afterward (10).

\section{Translation and cultural adaptation of the original QLQ CX 24 questionnaire}

According to the guiding principle of the International Society for Pharmacoeconomics and Outcomes Research (ISPOR), translation and cultural adaptation of the QLQ CX 24 were finished (11). The 24-item QLQ CX 24 was originally designed to consist of five multi-item scales on clinically different dimensions (sexual functioning, body image, and gastrointestinal, urologic, and vaginal symptoms) and several single-item measures. The original questionnaire has the following subscales: Symptom Experience, Body Image, Sexual/Vaginal Functioning, and 5 single-item scales: Lymphedema, Peripheral Neuropathy, Menopausal Symptoms, Sexual Worry, Sexual Activity, and Sexual Enjoyment. In the beginning, the original scale was primarily translated from English to Serbian by two independent native Serbian language speakers, an expert translator, and a bilingual 
university professor. They translated the questionnaire separately from each other, and then they gathered and the translations were synchronized to one Serbian version. The synchronized Serbian version was then translated reverse to English by a native English language speaker, who was not responsive to the original English version of the QLQ CX 24. Researchers then compared the back-translation to English was with the original English version, and the final Serbian version of the QLQ CX 24 was agreed upon at the new meeting of investigators. Finally finishing the translation of QLQ CX 24 to Serbian was then tested on 10 female inpatients with cervical cancer at the Oncology Clinic, Clinical Center Kragujevac, Serbia. Following the pilot testing, the minor changes of the wording were made, and then the final Serbian version of the QLQ CX 24 was copied and organized for testing. Also, with a specially designed questionnaire, we collected demographic data about patients $(10,12,13)$.

Serbian version of QLQ CX 24, the Serbian version of the QLQ C30 Questionnaire, and the Serbian version of the Emotion Regulation Questionnaire were finished by the females themselves and by the researchers after interviewing the females. Chronological stability of the translated QLQ CX 24 was tested by the repeated achievement of the questionnaire 30 days after the first one.

\section{Statistics}

Kolmogorov-Smirnov test was used to test if answers to the questionnaires were normally distributed, in the case that the answers were not distributed normally, nonparametric tests were used. The consistency of the Serbian version of QLQ CX 24 was checked by measuring the inner stability through the result of the Cronbach's alpha. Through investigation of the correlation of the individual items, convergent validity was assessed with the total score of the QLQ C30 and ERQ instruments. For all tests of criterion and convergent validity, we calculated Spearman's level correlations. When the answers were not normally dispersed factor structure of the Serbian translation of QLQ CX24 was examined by the method of principal axis factoring $(12,13)$. According to the condition that eigenvalues had to be superior to 1 , new factors were extracted. The factors we extracted were then compared with their respective QLQ CX24 items and therefore named (14).

All calculations in this study were performed by SPSS software, version 18. The stage of importance was set to $\mathrm{p}<$ 0.05 .

\section{RESULTS}

The original version of the QLQ CX 24 was tested on the sample of 100 female inpatients: mean age $51.55 \pm 12.63$ years, smokers being $33 \%$ of the patients (mean number of cigarettes $5.40 \pm 8.92$, mean years of smoking $6.77 \pm 10.98)$, and alcohol drinkers ( $5 \%$ of the patients)(Table 1$)$.

\section{Completing the questionnaires}

The usualtime taken of finishing all the questionnaires of the study was less than 45 minutes, and the duration of completing QLQ CX 24 was less than 20 minutes. Only 20 patients answered all questions in the three questionnaires. Most of the patients (about 80\%) answered the first 19 items of the QLQ CX 24. Therefore only answers to the first 19 questions of the QLQ CX 24 were entered to the statistical calculations of reliability and validity.

\section{Consistency and factor analysis}

We got results about mean values, variance, skewness and kurtosis of the distribution of responses to each of the questions, after testing the QLQ CX 24 questions (Table 2). When the scale was rated by researchers, Cronbach's alpha was 0.607 . We separated the questionnaire by split-half method (Spearman-Brown), and the coefficient for the questionnaire as a whole was calculated by the formula Spearman-Brown, and its significance was 0.579 . Reliability appears to be solid with the Cronbach's alpha of 0.802 after the questionnaire was rated by the females themselves (a week following the ranking by the researchers).

The measure of sampling adequacy (Kaiser-Meyer-Olkin) was 0.642 and Bartlett's test of sphericity was important $(\mathrm{p}<0.001)$. By orthogonal rotation six factors were extracted, illuminating in total $70.7 \%$ of the variance. The eigenvalue of the first factor was 5.37 (28.28\% of variance), of the second 2.59 (13.64 \% of the variance), of the third 1.84 (9.69\% of the variance), of the forth 1.44 (7.61\% of the variance), of the fifth 1.20 (6.35\% of the variance) and the sixth 1.04 (5.44 $\%$ of the variance). The rotated part matrix is exposed in Table 3. The cut-off point for transmission of the question to a factor was loading superior to one. The items 2 and 5 belong to the first factor, which reflects problems with both defecation and urination. The items 15, 16, 17 belong to the factor 2 and reflect the self-perception of physical appearance. Items 6 and 7 belong to the third factors and describe problems with urination. Factor 4 includes items 4, 8, 9, 12 and 13 and describes the feeling of being ill in general. The items 10 and 14 belong to the fifth factor and describe sensations of autonomic functions. The items 1, 11,18 and 19 belong to factor 6 and describe problems related to sexual activity.

\section{Validity and chronological stability}

Through non-parametric correlation between scores of the QLQ CX 24 (when it was rated by researchers and by females themselves) and scores of the QLQ-C30 (when it was rated by researchers and by females themselves), divergent criterion validity was tested. A score of the QLQ CX24 was calculated as the sum of individual items ratings for each of the patients. Through non-parametric correlation between scores of the QLQ CX 24 (when it was rated by researchers and by females themselves) and scores of the ERQ (when it was rated by researchers and by females themselves), convergent criterion validity was tested. According to the nonnormal distribution of some of the scores non-parametric 
correlation was used. Spearman's correlation coefficients are shown in multi-trait, multi-method matrix (Table 4). The Table 4 shows how items of the translated scale are grouped in six domains (factors) that reflect facets of the quality of life of patients with cervical cancer. Titles of the domains were given in an attempt to verbally describe aspect of quality of life that items within the domains are referring to. It is obvious from the Table 3 that main aspects of quality of life in patients suffering from cervical cancer relate to functional sphere (defecation and urination), loss of sexual function and distorted perception of physical appearance.

The QLQ CX 24 showed pleasing chronological stability: when rating (by explorer) was repeated on the same females one month later the correlation between the scores (Spearman's coefficients) was $0.831(\mathrm{p}=0.000)$. After the repeated rating Cronbach's alpha was 0.696 . The correlation coefficient of interclass was $0.607 \pm 0.483$ on the initial rating, and $0.693 \pm 0.599$ on repeated rating.

\section{DISSCUSION}

This study presents data from the translation and confirmation of the EORTC QLQ-CX 24. It is the first investigation to achieve a psychometric confirmation of the EORTC QLQ-CX 24 in a Balkan country, Serbia. The most important explanation why this study is significant is the fact that the morbidity and survival rate of cervical cancer is rising, which will guide to an increase in the need for tools able to review QOL of such patients. Moreover, the results show that the translation of the EORTC QLQ-CX24 to Serbian is crossculturally suitable in countries with Serbian-speaking populations.

The Serbian translation of the QLQ CX 24 showed solid reliability when was rated by the researcher as well as by females themselves. Our results showed that measures of chronological stability, correlations, and internal consistency with convergent or divergent scales were ahead of the values in the literature considered as sufficient to establish validity and reliability (15). The values from our study were moreover very similar to those obtained after testing the reliability and validity of the QLQ-C30 and QLQ CX $24(8,9)$. Factor analysis revealed six factors (Problems with defecation and urination; Self-perception of physical appearance; Problems with urination; Feeling of being ill in general; Sensations of autonomics function; Problems related to sexual activity).

The mean age of our patients (51.6 years) was similar to the patients included invalidation of QLQ CX 24 (9). In our sample $33 \%$ of females were smokers; almost all meta-analyses and multi-center investigations spot that smoking is a significant co-factor for cervical squamous cancer and maybe also for cervical adenocarcinoma (16). When original QLQ CX 24 was developed values of Cronbach's alpha varied from
0.72 to 0.87 which is similar to our results with Cronbach's $\alpha$ between 0.6 and 0.8 depending on if it was rated by investigators or by patients themselves (9). If we compare our results with results from validation in other countries, we will notice a similar outcome (17-21).

Our factor analysis revealed six factors (Problems with defecation and urination; Self-perception of physical appearance; Problems with urination; Feeling of being ill in general; Sensations of autonomics function; Problems related to sexual activity) so there are differences between original QLQ CX 24 and validated scale in our country. This could be explained with a different population structure in Serbia in comparison with the country where the original questionnaire was developed. We have received solid results regarding the validation of the questionnaire. The scale evidenced good item convergence $(\mathrm{r}=0.1-0.7)$, similar to the study in China (21) and Etiopia (20). Our study has several limitations. The sample size was relatively small (100), and the patients were enrolled successively, during one year, but they were very compliant with the study protocol, enabling testing of temporal stability and evaluation of testing mode effect. Uni-centricity is another limitation, which may have introduced the investigator's bias. The last limitation is that patients did not answer all questions. Most of the patients answered only the first 19 items of the QLQ CX 24. Therefore, only answers to the first 19 questions of the QLQ CX 24 were entered into the statistical calculations of reliability and validity. There could be many reasons why we got such a result. First, some of the patients had not sexual activity. Second, females felt shame to answer such questions. It should be noted that the questionnaire originated in developed countries and that Serbia is a developing country.

In conclusion, the QLQ CX 24 is a trustworthy and suitable specific instrument for measuring QOL in patients with cervical cancer, but patients need to fill the questionnaire by themselves. This translation supplements the range of instruments that can be used in clinical practice to measure the quality of life in such patients.

All authors declare no conflict of interest.

\section{ACKNOWLEDGMENT}

This work was supported by project of Faculty of Medical Sciences, University of Kragujevac, Serbia, project number JP 08/20. 
Table 1. Characteristics of the study sample

\begin{tabular}{|l|c|}
\hline Variable & $\begin{array}{c}\text { Mean } \pm \text { standard deviation*/median } \\
\text { (range)** }(\mathbf{n}=\mathbf{1 0 0})\end{array}$ \\
\hline Age (years) & $51.55 \pm 12.63$ \\
\hline Smokers & $33(33 \%)$ \\
\hline Number of cigarettes & $5-40$ \\
\hline Years of smoking & $1-45$ \\
\hline Alcohol consumption & $5(5 \%)$ \\
\hline Type of tumor & $71(71 \%)$ \\
\hline Carcinoma planocellulare & $29(29 \%)$ \\
\hline Adenocarcinoma & $1-4$ \\
\hline Charlson Comorbidity Index & $71(71 \%)$ \\
\hline Chemotherapy & $89(89 \%)$ \\
\hline Radiotherapy & $30(30 \%)$ \\
\hline Surgery & \\
\hline \multicolumn{2}{|c}{} \\
*Data were normally distributed; $*$ Data were not normally distributed. \\
\hline
\end{tabular}

Table 2. Mean values, standard deviation, skewness and kurtosis of responses to items of QLQ CX 24

\begin{tabular}{|l|c|c|c|c|c|}
\cline { 2 - 5 } \multicolumn{1}{l|}{} & $\begin{array}{c}\text { Number } \\
\text { of } \\
\text { patients }\end{array}$ & Mean & $\begin{array}{c}\text { Std. } \\
\text { Deviation }\end{array}$ & Skewness & Kurtosis \\
\hline $\begin{array}{l}\text { Have you had cramps in your } \\
\text { abdomen? }\end{array}$ & 100 & 2.390 & 1.332 & 1.104 & 1.254 \\
\hline $\begin{array}{l}\text { Have you had difficulty in } \\
\text { controlling your bowels? }\end{array}$ & 100 & 1.980 & 0.994 & 0.543 & -0.924 \\
\hline $\begin{array}{l}\text { Have you had blood in your } \\
\text { stools (motions)? }\end{array}$ & 100 & 1.410 & 0.697 & 1.421 & 0.565 \\
\hline $\begin{array}{l}\text { Did you pass water/urine fre- } \\
\text { quently? }\end{array}$ & 100 & 2.310 & 0.981 & -0.008 & -1.129 \\
\hline $\begin{array}{l}\text { Have you had pain or a burn- } \\
\text { ing feeling when passing wa- } \\
\text { ter/urinating? }\end{array}$ & 100 & 1.860 & 0.804 & 0.380 & -1.011 \\
\hline $\begin{array}{l}\text { Have you had leaking of } \\
\text { urine? }\end{array}$ & 100 & 1.840 & 2.966 & 6.463 & 42.677 \\
\hline $\begin{array}{l}\text { Have you had difficulty emp- } \\
\text { tying your bladder? }\end{array}$ & 100 & 1.660 & 2.170 & 8.492 & 79.682 \\
\hline $\begin{array}{l}\text { Have you had swelling in one } \\
\text { or both legs? }\end{array}$ & 100 & 1.730 & 0.885 & 1.007 & 0.109 \\
\hline $\begin{array}{l}\text { Have you had pain in your } \\
\text { lower back? }\end{array}$ & 100 & 2.090 & 1.518 & 4.086 & 22.518 \\
\hline $\begin{array}{l}\text { Have you had tingling or } \\
\text { numbness in your hands or } \\
\text { feet? }\end{array}$ & 100 & 1.740 & 1.235 & 4.475 & 31.124 \\
\hline $\begin{array}{l}\text { Have you had irritation or } \\
\text { soreness in your vagina or } \\
\text { vulva? }\end{array}$ & 100 & 1.870 & 0.895 & 0.865 & 0.054 \\
\hline $\begin{array}{l}\text { Have you had discharge from } \\
\text { your vagina? }\end{array}$ & 1.570 & 0.685 & 0.991 & 0.564 \\
\hline
\end{tabular}




\begin{tabular}{|l|c|c|c|c|c|}
\cline { 2 - 6 } \multicolumn{1}{l|}{} & $\begin{array}{c}\text { Number } \\
\text { of } \\
\text { patients }\end{array}$ & Mean & $\begin{array}{c}\text { Std. } \\
\text { Deviation }\end{array}$ & Skewness & Kurtosis \\
\hline $\begin{array}{l}\text { Have you had abnormal bleed- } \\
\text { ing from your vagina? }\end{array}$ & 100 & 1.750 & 0.845 & 0.915 & 0.095 \\
\hline $\begin{array}{l}\text { Have you had hot flushes } \\
\text { and/or sweats? }\end{array}$ & 100 & 2.390 & 1.469 & 4.011 & 22.427 \\
\hline $\begin{array}{l}\text { Have you felt physically less } \\
\text { attractive as a } \\
\text { result of your disease or treat- } \\
\text { ment? }\end{array}$ & 100 & 1.650 & 0.936 & 1.136 & -0.014 \\
\hline $\begin{array}{l}\text { Have you felt less feminine as } \\
\text { a } \\
\text { result of your disease or treat- } \\
\text { ment? }\end{array}$ & 100 & 1.720 & 0.943 & 1.033 & -0.112 \\
\hline $\begin{array}{l}\text { Have you felt dissatisfied with } \\
\text { your body? }\end{array}$ & 100 & 1.760 & 1.016 & 1.031 & -0.264 \\
\hline $\begin{array}{l}\text { Have you worried that sex } \\
\text { would be painful? }\end{array}$ & 99 & 1.798 & 1.049 & 0.903 & -0.641 \\
\hline $\begin{array}{l}\text { Have you been sexually ac- } \\
\text { tive? }\end{array}$ & 96 & 1.645 & 0.994 & 1.291 & 0.308 \\
\hline $\begin{array}{l}\text { Has your vagina felt dry dur- } \\
\text { ing sexual activity? }\end{array}$ & 21 & 2.523 & 0.980 & -0.249 & -0.833 \\
\hline Has your vagina felt short? & 20 & 2.700 & 1.080 & -0.439 & -0.974 \\
\hline Has your vagina felt tight? & 20 & 2.500 & 1.100 & -0.132 & -1.259 \\
\hline $\begin{array}{l}\text { Have you had pain during sex- } \\
\text { ual intercourse or other sexual } \\
\text { activity? }\end{array}$ & 20 & 2.800 & 1.005 & -0.594 & -0.490 \\
\hline $\begin{array}{l}\text { Was sexual activity enjoyable } \\
\text { for you? }\end{array}$ & 20 & 2.100 & 0.911 & 0.713 & 0.154 \\
\hline
\end{tabular}

Table 3. The rotated component matrix of QLQ CX 24 with factor loading per each item. Items within the shaded cells belong to the corresponding factor. Number of patients who responded: 100.

The cut off point for assigning an item to a factor was loading greater than one.

\begin{tabular}{|l|c|c|c|c|c|c|}
\cline { 2 - 7 } \multicolumn{1}{c|}{} & \multicolumn{5}{c|}{ FACTORS } \\
\cline { 2 - 7 } & $\begin{array}{c}\text { Problems } \\
\text { with defe- } \\
\text { cation and } \\
\text { urination }\end{array}$ & $\begin{array}{c}\text { Self-percep- } \\
\text { tion of } \\
\text { physical ap- } \\
\text { pearance }\end{array}$ & $\begin{array}{c}\text { Problems } \\
\text { with uri- } \\
\text { nation }\end{array}$ & $\begin{array}{c}\text { Felling of } \\
\text { being ill in } \\
\text { general }\end{array}$ & $\begin{array}{c}\text { Sensations } \\
\text { of auto- } \\
\text { nomic func- } \\
\text { tions }\end{array}$ & $\begin{array}{c}\text { Prob- } \\
\text { lems re- } \\
\text { lated to } \\
\text { sexual } \\
\text { activity }\end{array}$ \\
\hline $\begin{array}{l}\text { Have you had } \\
\text { cramps in your ab- } \\
\text { domen? }\end{array}$ & 0.074 & 0.091 & 0.129 & -0.005 & -0.061 & 0.379 \\
\hline $\begin{array}{l}\text { Have you had diffi- } \\
\text { culty in controlling } \\
\text { your bowels? }\end{array}$ & 0.497 & -0.019 & -0.022 & -0.052 & 0.315 & -0.091 \\
\hline $\begin{array}{l}\text { Have you had blood } \\
\text { in your stools (mo- } \\
\text { tions)? }\end{array}$ & -0.064 & 0.040 & 1.000 & -0.077 & -0.076 & 0.186 \\
\hline $\begin{array}{l}\text { Did you pass wa- } \\
\text { ter/urine fre- } \\
\text { quently? }\end{array}$ & 0.167 & -0.152 & -0.018 & 0.704 & 0.173 & 0.004 \\
\hline
\end{tabular}




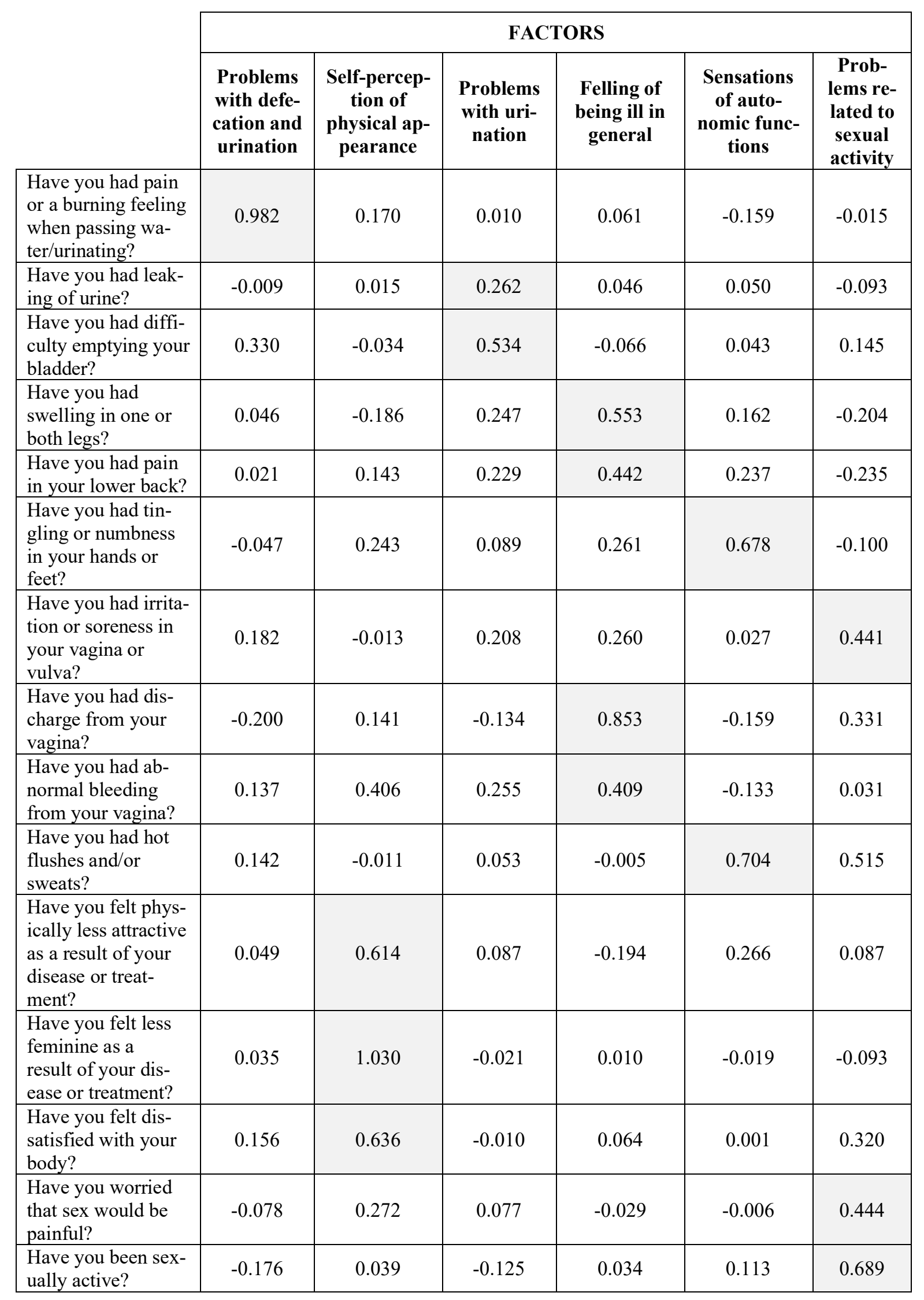


Table 4. Multi-trait, multi-method correlation matrix (non-parametric Spearman's coefficients).

Number of patients who responded: 100

\begin{tabular}{|c|c|c|c|c|c|c|}
\hline & $\begin{array}{l}\text { QLQ C30 } \\
\text { rated by in- } \\
\text { vestigator }\end{array}$ & $\begin{array}{l}\text { ERQ rated by } \\
\text { investigator }\end{array}$ & $\begin{array}{l}\text { QLQ C30 } \\
\text { rated by a pa- } \\
\text { tient }\end{array}$ & $\begin{array}{c}\text { ERQ rated by } \\
\text { a patient }\end{array}$ & $\begin{array}{l}\text { QLQ CX } 24 \\
\text { rated by inves- } \\
\text { tigator }\end{array}$ & $\begin{array}{c}\text { QLQ CX } 24 \\
\text { rated by a } \\
\text { patient }\end{array}$ \\
\hline $\begin{array}{l}\text { QLQ C30 } \\
\text { rated by } \\
\text { investigator }\end{array}$ & 1 & $\begin{array}{c}\text { Rho }=0.007 \\
\mathrm{p}=0.948\end{array}$ & $\begin{array}{c}\text { Rho }=0.738 \\
\mathrm{P}=0.000\end{array}$ & $\begin{array}{c}\text { Rho }=0.091 \\
\mathrm{P}=0.369\end{array}$ & $\begin{array}{c}\text { Rho }=0.347 \\
p=0.001\end{array}$ & $\begin{array}{c}\text { Rho }=0.196 \\
\mathrm{p}=0.058\end{array}$ \\
\hline $\begin{array}{l}\text { ERQ rated by } \\
\text { investigator }\end{array}$ & $\begin{array}{c}\text { Rho }=0.007 \\
\mathrm{p}=0.948\end{array}$ & 1 & $\begin{array}{c}\text { Rho }=-0.043 \\
p=0.668\end{array}$ & $\begin{array}{c}\text { Rho }=0.915 \\
\mathrm{p}=0.000\end{array}$ & $\begin{array}{c}\text { Rho }=-0.151 \\
p=0.142\end{array}$ & $\begin{array}{c}\text { Rho }=-0.124 \\
p=0.232\end{array}$ \\
\hline $\begin{array}{l}\text { QLQ C30 } \\
\text { rated by a } \\
\text { patient }\end{array}$ & $\begin{array}{c}\text { Rho }=0.738 \\
p=0.000\end{array}$ & $\begin{array}{c}\text { Rho }=-0.043 \\
p=0.668\end{array}$ & 1 & $\begin{array}{c}\text { Rho }=-0.102 \\
p=0.310\end{array}$ & $\begin{array}{c}\text { Rho }=0.227 \\
p=0.026\end{array}$ & $\begin{array}{c}\text { Rho }=0.284 \\
\mathrm{p}=0.006\end{array}$ \\
\hline $\begin{array}{c}\text { ERQ rated by } \\
\text { a patient }\end{array}$ & $\begin{array}{c}\text { Rho }=0.091 \\
p=0.369\end{array}$ & $\begin{array}{c}\text { Rho }=0.915 \\
p=0.000\end{array}$ & $\begin{array}{c}\text { Rho }=-0.102 \\
\mathrm{p}=0.310\end{array}$ & 1 & $\begin{array}{c}\text { Rho }=-0.088 \\
p=0.396\end{array}$ & $\begin{array}{c}\text { Rho }=-0.212 \\
\mathrm{p}=0.040\end{array}$ \\
\hline $\begin{array}{l}\text { QLQ CX } 24 \\
\text { rated by in- } \\
\text { vestigator }\end{array}$ & $\begin{array}{c}\text { Rho }=0.347 \\
\mathrm{p}=0.001\end{array}$ & $\begin{array}{c}\mathrm{Rho}=-0.151 \\
\mathrm{p}=0.142\end{array}$ & $\begin{array}{c}\text { Rho }=0.227 \\
\mathrm{p}=0.026\end{array}$ & $\begin{array}{c}\text { Rho }=-0.088 \\
p=0.396\end{array}$ & 1 & $\begin{array}{c}\text { Rho }=0.774 \\
p=0.000\end{array}$ \\
\hline $\begin{array}{l}\text { QLQ CX } 24 \\
\text { rated by a } \\
\text { patient }\end{array}$ & $\begin{array}{c}\text { Rho }=0.196 \\
\mathrm{p}=0.058\end{array}$ & $\begin{array}{c}\text { Rho }=-0.124 \\
p=0.232\end{array}$ & $\begin{array}{c}\text { Rho }=0.284 \\
\mathrm{p}=0.006\end{array}$ & $\begin{array}{c}\text { Rho }=-0.212 \\
p=0.040\end{array}$ & $\begin{array}{c}\text { Rho }=0.774 \\
p=0.000\end{array}$ & 1 \\
\hline
\end{tabular}

\section{REFERENCES}

1. Dahiya N, Acharya AS, Bachani D et al.Quality of Life of Patients with Advanced Cervical Cancer before and after Chemo-radiotherapy. Asian Pac J Cancer Prev 2016;17: 3095-9.

2. XieY, Zhao FH, Lu SH et al. Assessment of QOL for the patients with cervical cancer at different clinical stages. Chin J Cancer 2013; 32: 275-282.

3. Ferlay J, Soerjomataram I, Ervik M, et al. GLOBOCAN 2012 v1.0, Cancer Incidence and Mortality Worldwide: IARC CancerBase No. 11 [Internet]. Lyon, France: International Agency for Research on Cancer; Available from: http:// globocan.iarc.fr2013, Accessed on October 102019.

4. Khalil J, Bellefqih S, Sahli N, et al.Impact of cervical cancer on quality of life:beyond the short term (Results from a single institution). GynecolOncol Res Pract2015;2:7.

5. Pfaendler KS, Wenzel L, Mechanic MB, et al. Cervical cancer survivorship: Long-term quality of life and social support. ClinTher2015 ; 37: 39-48.

6. Athanasiou S, Pitsouni E, Grigoriadis T, et al.A study protocol of vaginal laser therapy ingynecological cancer survivors. Climacteric2019; 2:1-6.
7. Tax C, Steenbergen M, Zusterzeel P, et al.Measuring health-related quality of life in cervical cancer patients: a systematic review of the most used questionnaires and their validity. BMC Med Res Methodol. 2017; 17: 15.

8. Aaronson NK, Ahmedzai S, Bergman B, et al.The European Organization for Research and Treatmentof Cancer QLQ-C30: A Quality-of-Life Instrumentfor Use in International Clinical Trials in Oncology. J Natl Cancer Inst1993; 85: 365-76.

9. Greimel ER, Kuljanic Vlasic K, Waldenstrom AC, et al; European Organization for Research and Treatment of Cancer Quality-of-Life Group.The European Organization for Research and Treatment of Cancer (EORTC) Quality-of-Life questionnaire cervical cancer module: EORTC QLQ-CX24. Cancer2006; 107: 1812-22.

10. Jankovic S, Antonijevic G, Vasic I et al. A rating instrument for fear of hospitalization. J Clin Nurs. 2018 ;27(78):1431-1439. doi: 10.1111/jocn.14295.

11. 11.Wild D, Grove A, Martin M et al. ISPOR Task Force for Translation and Cultural Adaptation. Principles of good practice for the translation and cultural adaptation process for patient-reported outcomes (PRO) measures: report of the ISPOR Task Force for Translation and Cultural Adaptation. Value Health 2005 ;8(2): 94-104.

12. 12.Jankovic SM, Andjelkovic M, Zaric RZ et al.The psychometric properties of the Comprehensive Headache-related Quality of life Questionnaire (CHQQ) 
translated to Serbian.Springerplus 2016 ; 5(1):1416. doi: 10.1186/s40064-016-3109-1.

13. Živković Zarić R, Janković S, Csépány É et al.Psychometric properties of the Headache Under-Response to Treatment (HURT) questionnaire and the Migraine Disability Assessment Test (MIDAS) translated to Serbian. Vojnosanit Pregl 2019; 76(11): 1162-1168.

14. Fabrigar LR, Wegener DT, MacCallum RC et al.Evaluating the use of exploratory factor analysis in psychological research. Psychol Methods 1999 ;4(1): 272-299.

15. Bolarinowa OA.Principles and methods of validity and reliability testing questionnaires used in social and health science researches. Niger Postgrad Med J 2015; 22: 195-201.

16. Fonseca-Moutinho JA. Smoking and Cervical Cancer. ISRN ObstetGynecol $2011 ; 2011: 847684$.

17. Paradowska D, Tomaszewski KA, Bałajewicz-Nowak $\mathrm{M}$ et al.Validation of the Polish version of the EORTC QLQ-CX24 module for the assessment of health-related quality of life in women with cervical cancer. Eur J Cancer Care (Engl) 2014; 23(2):214-20.

18. Shin DW, Ahn E, Kim YM et al. Cross-Cultural Application of the Korean Version of the European Organization for Research and Treatment of Cancer Quality of
Life Questionnaire Cervical Cancer Modul. Oncology 2009; 76(3):190-8.

19. Jayasekara H, Rajapaksa LC, Greimel ER.The EORTC QLQ-CX24 cervical cancer-specific qualityof life questionnaire: psychometric properties in a South Asian sample of cervical cancer patients. Psychooncology 2008 ;17(10): 1053-7.

20. Araya LT, Gebretekle GB, Gebremariam GT et al.Reliability and validity of the Amharic version of European Organization for Research and Treatment of cervical Cancer module for the assessment of health related quality of life in women with cervical cancer in Addis Ababa, Ethiopia. Health Qual Life Out 2019; 17(1): 13.

21. Hua CH, Guo HM, Guan XL et al. Validation of the european Organization for research and Treatment of cancer cervical cancer module for chinese patients with cervical cancer. Patient Prefer Adherence 2013; 7: 1061-6. 